\title{
Institutional isomorphism, self-organisation and the adoption of management controls
}

\author{
Joshua Mandre ${ }^{1, a}$, Joseph M. Ntayi ${ }^{\text {a }}$, Levi B. Kabagambe ${ }^{\text {a }}$ \\ and James Kagaari ${ }^{\text {b }}$ \\ ${ }^{a}$ Makerere University Business School, Kampala, Uganda \\ ${ }^{b}$ Kyambogo University, Kampala, Uganda
}

\begin{abstract}
Research Question: The purpose of this study is to examine whether self-organisation mediates the relationship between institutional isomorphism and the adoption of management controls.

Motivation: Research on institutions has tended to emphasize how organizational processes are shaped by institutional forces that reinforce continuity and reward conformity. Such insight raises the question of how actors ever imagine changing institutions.

Idea: The study blends institutionalism with complexity theory, for a better understanding of the micro/macro dynamics of organizations which lead to organizations adopting management controls.
\end{abstract}

Data: The study employed a cross-sectional survey to collect data from 202 manufacturing firms, with the help of a multi-dimensional self-administered questionnaire.

Tools: Data were analysed quantitatively using descriptive statistics, and PLS-SEM. The nature and strength of the relationships between the variables was tested using the bootstrapping method

Findings: This study established that organisations adopt management controls, as a means of reacting to isomorphic pressures present in the environment. However, the adoption process is enhanced by the self-organising capacity of the staff, within the firms.

Contribution: The study represents a novel attempt to blend institutional and complexity theories in order to explain how organization actors can transform institutions in which they are embedded.

\footnotetext{
${ }^{1}$ Corresponding author: Joshua Mandre, Makerere University Business School, Kampala, Uganda, Tel. (+256) 772999861, email address: joshua.mandre@ gmail.com
} 
Keywords: adoption, management control, self-organisation, institutional theory.

JEL Classification: M410 Accounting

\section{Introduction}

It is important for firms to recognize the necessity of organizational change, and proactively cope with environmental variations, to secure sustainable competitive advantage, and survive, in today's business environment (Jung et al., 2020). Firms are faced with growing environmental pressure, characterised by mounting regulatory forces, more knowledgeable and demanding customers, a complex supplier base and increased competition from multinational enterprises, among others (Du \& Zhou, 2019). These numerous changes appear to contribute to greater complexity within and outside organizations. Moreover, responding to such changes often requires engaging in complex interactions with a wide variety of internal and external stakeholders. All of this has massive implications for how organizational actors respond to and manage this complexity (Dick et al., 2017 ).

It is posited that adopting management controls can enable firms mount an appropriate response to this pressure, since management control plays a critical role in ensuring firms gain a sustainable competitive advantage, and enhanced performance (Simons, 2010), by helping managers to formulate business strategies, specify the operational actions required to implement these strategies, clarify mutual expectations, identify operational improvements, and set targets that may influence current and subsequent performance (Bourne et al., 2018).

Several scholars have then argued that the firm's decision to adopt management controls is a means of adapting to a socially constructed environment (Ax \& Greve, 2017). According to Institutional theory, organizations in uncertain environments don't just seek the rationalization of processes, but also legitimacy through organizational structures and practices that are similar to those in the organizational field (De Prá Carvalho et al., 2017). They become isomorphic with their environment (Meyer \& Rowan, Institutionalized Organizations: Formal Structure as Myth and Ceremony, 1977). This explains similarity in organizational practices that have been adopted (De Prá Carvalho et al., 2017) such as management controls.

These arguments emphasize how organizational processes are shaped by institutional forces that reinforce continuity and reward conformity (Garud et al., 2007). This conceptualization implies institutions as highly rigid and constraining (Zhao et al., 2017). Such insight has led to criticism of institutional theory for its apparent inability to explain organizational transformation (Tracey et al., 2011), by 
ignoring the influence of institutional pressures on actors' behaviours (Battilana et $a l ., 2009)$. Yet, any understanding of institutionalization must explore the way ideals and forms of knowledge are inscribed in formalized practices and instruments of measurement and control (Abdelnour et al., 2017).

In contrast, according to literature, the complexity of the environment organizations are required to enact, or adapt to, reflects human cultural activity, and level of development. These shape both, the forces that an organization must respond to, as well as the representations and behavioural dispositions through which the response is channelled (Boisot \& McKelvey, 2011). Complex systems, such as organizations, are capable of learning from their experience, adapting and responding to changes in the external environment (Poutanen et al., 2016). In such systems, agents communicate, learn from each other, and their environment, and then adjust their behaviour accordingly. As such, the system is best described as a Complex Adaptive System (CAS), meaning that it has the capability to self-organize (Anzola et al., 2017). Through the interactions, global system patterns emerge and new factors (e.g., technology, policy, novel relationships, practices) eventuate (Braithwaite et al., 2018). Implying that a Complexity theory lens can be useful in understanding 'perpetuation of the status quo' as well as novelty and innovation (Tenbensel, 2013). This offers some provocative new insights and metaphors for constructing a new perspective on 'management control' in and of complex systems (Thrane \& Leitner, 2010).

This has led to the suggestion to blend institutionalism with complexity theory for a better understanding of the macro / micro dynamics of organisations. This is possible since there is a complementarity in which complexity theory supplies the micro mechanisms lacking in institutional theory and institutional theory supplies a macro framing specific to organisations which complexity theory lacks (Room, 2011). The institutional change at the macro level requires a series of changes and adaptations at the micro (organizational) level (Aoki, 2007 cited in Roszkowska-Menkesa \& Aluchnab, 2017).

Therefore, there is a need to identify ways in which institutional isomorphism is strengthened in the contexts of intentional and episodic organizational change facilitated by internal change agents, such as the management and staff (Kontinen \& Onali, 2017). When linked to wider institutions, the variation in practice that results from the enactment and performativity of rules and routines at micro levels can significantly contribute to understanding innovation and institutional change (Abdelnour et al., 2017).

The purpose of this study, then, is to combine institutional and complexity theories in order to develop a theoretical framework that explains the adoption of management controls. Specifically, this study sets out to examine whether selforganisation mediates the relationship between institutional isomorphism and the adoption of management controls. The empirical findings are in support of the 
hypothesised relationships and corroborate the theoretical assertion that selforganisation mediates the relationship between institutional isomorphism and adoption of management controls. Additionally, this study concludes that institutional isomorphism and self-organisation are important enablers of adoption of management controls.

This study makes three contributions to the field of management control. First, by combining conceptual lenses, this research demonstrates a congruence between institutional theory and Complex Adaptive Systems (CAS). We therefore respond to the aforementioned calls to build a connection between institutional and complexity theories.

Secondly, this study confirms the results of previous studies, which have posited a positive relationship between institutional isomorphic pressure and adoption of administrative innovations in organisations, in this case management controls. This has been applied in the context of manufacturing firms.

Thirdly, how accounting and governance practices can contribute to the success of businesses in emerging economies continues to attract significant attention from researchers, policy-makers, and practitioners (Soobaroyen et al., 2017). However, in the context of developing countries, little is known about MAS knowledge diffusion in LDCs, yet their accounting needs and concerns are as pressing - if not more so as in rich countries (Hopper et al., 2009). Few of them have analysed the adoption of MA tools in in developing countries (Erokhin et al., 2019).

In the Ugandan context, there are some few studies that have examined aspects of management control. For example, Nkundabanyanga, et al. (2018) studied management accounting practices in Ugandan secondary schools. Nkundabanyanga, et al. (2017) also looked at the effect of financial management practices and competitive advantage on loan performance of microfinance institutions (MFIs), and Nantunda, et al. (2020) whose results indicate that control activities within the guidelines, segregated duties and IT environment in private schools' financial management are ensured in the mobilization of desired revenue. In any case, these studies do not examine management control in manufacturing firms. An exception is Namakonzi and Inanga (2014) who studied environmental management accounting and environmental management, in manufacturing industries in Uganda.

There is, therefore, a compelling case for research approaches and theoretical perspectives which can illuminate and better explain accounting and governance practice in Africa (Soobaroyen et al., 2017). This study has provided an empirical explanation of how manufacturing firms in LDC's can identify, acquire and implement management controls, so as to enable firms improve their profitability and long-term survival.

The remainder of this paper is structured as follows: the next section presents a review of the relevant literature, and develops the relevant hypotheses. This is 
followed by the method section. The results are then presented, followed by discussion of the results. Contributions, implications, limitations of the study and insights for future research are provided.

\section{Literature review and hypotheses development 2.1 The adoption of management controls}

There exist a number of different conceptualizations and interpretations of what control is, what are management control systems, what is a management system and how this is different from management control system, and so on (Malmi, 2013). This study defines management controls to include all the devices and systems managers use to ensure that the behaviours and decisions of their employees are consistent with the organisation's objectives and strategies (Malmi \& Brown, Management control systems as a package - Opportunities, challenges and research directions, 2008), so as to contribute to organizational performance (Speklé \& Kruis, 2014). These mechanisms are formal controls, such as elements of organizational structure, written rules, standard operating systems, precise reward structures and criteria for evaluation and informal control, which involves professional and cultural controls which emanate from the shared norms and values in organizations and the socialization of members to these values (Malek et al., 2018). Given that the array of mechanisms that form part of management control efforts is extensive, the control categories used in this study are as follows: planning, measurement, compensation, structure, policies and procedures, and socio-ideological (Bedford \& Malmi, 2015).

Adoption covers how an organization becomes aware of new ideas, acquires, adapts, and uses them. The adoption process is grouped into three general phases of initiation, decision and implementation - representing pre-adoption activities, the managerial decision to adopt and post-adoption activities, respectively (Damanpour \& Aravind, 2012). Therefore, in this study, the adoption of management controls is centred on explaining how those systems, rules, practices, values, and other activities management put in place, in order to direct employee behaviour, can be identified, acquired and implemented, so as to enable firms improve their profitability and longterm survival.

\subsection{Institutional isomorphism and adoption of management controls}

We ask why there is such startling homogeneity of organizational forms and practices? (Meyer \& Rowan, 1977). The concept that best captures this process of homogenization is isomorphism (DiMaggio \& Powell, 1983). Isomorphism is 'a constraining process that forces one unit in a population to resemble other units that face the same set of environmental conditions' (Hawley (1968) cited in DiMaggio \& Powell, 1983). According to Meyer and Rowan (1977), organizations are structured by phenomena in their environments and tend to become isomorphic with them. Therefore, accounting systems or standards usually emerge in response to 
isomorphism to the institutional environment (Meyer \& Scott, 1991). DiMaggio and Powell (1983), identify three mechanisms through which institutional isomorphic change occurs, each with its own antecedents.

Coercive isomorphism results from both formal and informal pressures exerted on organizations by other organizations upon which they are dependent and by cultural expectations in the society within which organizations function. In some circumstances, organizational change is a direct response to government mandate: For example, Sadress and Bananuka (2019) find a positive significant relationship between coercive isomorphic forces and adoption of tax compliance behaviours among small business enterprises. The existence of a common legal environment also affects many aspects of an organization's behaviour and structure. Iredele $e t$ al. (2019) surveyed EMA practice adoption among firms in South Africa. They find that coercive pressure (activities of government through its regulatory efforts, labour unions, financial institutions, environmental groups, customers and local communities) has the greatest effect on the level of EMA practices, implying that without pressure from relevant stakeholders (which establishes guidelines and binds organisations to accounting procedures and practices related to environmental management), the organisation will be less likely to adopt EMA.

Direct imposition of standard operating procedures and legitimated rules and structures also occurs outside the governmental arena. Subsidiaries must adopt accounting practices, performance evaluations, and budgetary plans that are compatible with the policies of the parent corporation. In a critical evaluation of the decision of the Bangladeshi accounting profession to adopt all applicable International Accounting Standards, Mir and Rahaman, (2002) find evidence of immense pressure that major international donor/lending institutions put on the Bangladeshi government and professional accounting bodies to adopt International Accounting Standards (IASs), not only to provide credibility to foreign investors, but also ensure that accountability arrangements with lending/donor agencies are tight enough. Clearly, the government and other institutions in Bangladesh had very little option (if any at all) because of the country's high dependence on aid.

Not all institutional isomorphism, however, derives from coercive authority. Uncertainty is also a powerful force that encourages imitation. When the environment creates symbolic uncertainty, organizations may model themselves on other organizations in their field that they perceive to be more legitimate or successful. Models may be diffused unintentionally, indirectly through employee transfer or turnover, or explicitly by organizations such as consulting firms or industry trade associations (DiMaggio \& Powell, 1983). Munir et al. (2011) find that the adoption of the balanced score card, activity-based costing, and just-in-time production are examples of firms responding to mimetic isomorphic pressures. Additionally, Mohammed (2010) reports on the results of a study focused on how management accounting and control systems (MCS) operate in four commercial 
banks in Nigeria. The key factors identified as shaping the operations of the MCS were the need to comply with the regulatory environment (coercive isomorphism), the need to maintain social and cultural support (normative isomorphism) and the need to imitate successful organisations in order to appear legitimate (mimetic isomorphism).

A third source of isomorphic organizational change is normative and stems primarily from professionalization. Two aspects of professionalization are important sources of isomorphism. One is the resting of formal education and of legitimation in a cognitive base produced by university specialists: the second is the growth and elaboration of professional networks that span organizations and across which new models diffuse rapidly. Universities and professional training institutions are important centres for the development of organizational norms among professional managers and their staff. To the extent managers and key staff are drawn from the same universities and filtered on a common set of attributes, they will tend to view problems in a similar fashion, see the same policies, procedures and structures as normatively sanctioned and legitimated, and approach decisions in much the same way (DiMaggio \& Powell, 1983). In a study that examined the relationship between tax fairness, isomorphic forces, strategic responses and tax compliance in Ugandan small and medium enterprises (SMEs), Musimenta et al. (2017) find that the most important forces were seen to be regulatory expectations followed by professionalism and mimicry. Therefore, strengthening isomorphic forces will compel taxpayers to fulfil their tax obligation and, hence, do away with tax-evasion tendencies.

However, DiMaggio and Powell (1983) warn that this typology is an analytic one: the types are not always empirically distinct. Yet, while the three types intermingle in empirical setting, they tend to derive from different conditions and may lead to different outcomes.

H1. There is a positive relationship between institutional isomorphism and adoption of management controls.

\subsection{Self-organisation and adoption of management controls}

Self-organisation essentially refers to a spontaneous, dynamically produced (re-) organisation. The particularity of self-organised systems is their capacity to spontaneously (without external control) produce a new organisation, in case of environmental changes (Serugendo et al., 2006). Social behaviour of humans is also self-organised, and gives rise to emergent complex global behaviours. Furthermore, self-organisation implies organisation, which in turn implies some ordered structure and component behaviour. In this respect, the process of self-organisation changes 
the respective structure and behaviour and a new distinct organisation is selfproduced (Serugendo et al., 2004).

Self-organisation can enable an organisation to generate its own management controls from inner guidelines, rather than from external imposition, in order to cope with its environment (Cilliers, 1998). By employing mechanisms based on reinforcement, coupled with local interactions and local computations done by agents, management can engineer the agents to dynamically modify their behaviour, and self-organise, in order to provide a final coherent global state (Serugendo et al., 2004). These behaviours, such as an organization culture, performance measurement systems, and strategic planning, are then referred to as management controls (Hassas et al., 2006).

This approach to self-organisation consists of the following basic principles: rewards increase agent behaviour and punishments decrease agent behaviour. In this method, agents dynamically select a new behaviour (or action) based on the calculation of a probability value which is dependent on the current agent state and the perceived state of the environment, as well as on the quality of the previous adaptation decisions (Serugendo et al., 2006).

The task of those responsible for the strategic direction of an organization is not to foresee the future or to implement enterprise-wide adaptation programs, because nonlinear systems react to direction in ways that are difficult to predict or control. Rather, such managers establish and modify the direction and the boundaries within which effective, improvised, self-organized solutions can evolve. They set constraints upon local actions, observe outcomes, and tune the system by altering the constraints, all the while raising or lowering the amount of energy injected into the dissipative structure they are managing. Changes that produce positive cascades of change are retained, while those that do not are altered (Anderson, 1999). Indeed, it is well established that many innovations can arise from the bottom up, via selforganised groups that take it upon themselves, with little direction to solve a problem.

The total quality management literature, particularly that emphasizing quality circles and teams, explicates this process thoroughly (Smith, 2005). Concepts like reduction of variation, defined and standardized processes, management by fact, causal thinking, etc. all stem from the "Newtonian" paradigm of control and equilibrium, as manifested in the principles and practices of scientific management. Yet, TQM also has a learning component to it. Employee involvement, empowerment, and cross-functional cooperation are an important part of TQM. TQM thus has both mechanistic (control) and organismic (adaptive learning) components (Dooley, 1997).

An empirical study by Gazizulina et al. (2017) demonstrate how self-organization is an important factor in the processes of quality management systems that meet the 
requirements of the international standard ISO 9001. Their study shows how complexity of control actions structure leads to delegation of authority, for example planning, monitoring or assessment. The analysis and decision-making functions are delegated from the top management of an organization to its process managers; therefore, an employee performs the manager's functions and participates in the decision-making process. In the discussed circumstances, a management system of an organization becomes incapable of managing processes adequately without increasing its share of the self-organization process.

This means that control should be partial and facilitate effective behaviours for the emergence of adequate solutions. The challenge is to supply adequate incentives for cooperation, and protection of potential innovation rents, with a few simple boundary and interactive controls that facilitate the emergence of self-organised structures and systems. This is better done through control systems that focus on facilitating increased interaction around key indicators rather than detailing behaviours and goals. Control of complex systems should be focused on incentives for cooperative behaviour and open search processes that enable adaptation and cooperation (Thrane \& Leitner, 2010).

H2: Self-organisation is positively associated with the adoption of management controls.

\subsection{Institutional isomorphism, self-organisation, and adoption of management controls}

Organizations exist in an environment of institutions that exert some degree of pressure to which "individual organizations must conform, if they are to receive support and legitimacy" (Scott, 1995). In explaining the adoption of management controls, the environment represents the source of communications about an innovation (Nan, Zmud, \& Yetgin, 2014). However, even though institutional isomorphism influences the adoption of management controls, these isomorphic pressures are filtered by organizational actors (Beunen \& Patterson, 2019). Institutional pressures are interpreted, given meaning and represented by occupants of structural positions (Greenwood et al., 2011). Beginning with the level of local interactions, adoption takes place through a network consisting of individual units and the network provides connections through which an innovation spread (Rogers, 2010). Since adoption is a collective process that involves the contextual re-ordering of relations in multiple networks (Leeuwis \& Aarts, 2011), self-organisation then acts as coordinating device, enabling intra-firm learning and diffusion of know-how, facilitating access to complementary assets and providing an organisational platform to combine different competences required for adoption to happen (Oerlemans et al., 2007).

A complexity-based ontology thus recognizes both the functional and relational dependency between structurally integrated components of the system and the 
systemic environment or context. The properties of CAS come about and change because of the interplay between the adaptive responses of the components, and the context in which they operate (Preiser et al., 2018). In an organizational system, the context would include external meta-agents such as customers, competitors, suppliers, regulators, government, and the surrounding community (Dooley, 1997). The internal structure of CAS emerges from patterns of dynamic interaction between system elements on the one hand, and between the elements and their wider environment, on the other. As the context changes, the system will change and elements in the system may take on a different role or function (Preiser et al., 2018).

Organizational adoption decisions are then driven by the constraining or enabling characteristics of the field, organization, and innovation (Chandler \& Hwang, 2015). Institutions shape and constrain the processes of self-organized coordination, which socio-economic dynamics typically display (Dosi et al., 2019 ). While institutional pressures circumscribe the scope of organizational attention and shape adoption decisions by bestowing legitimacy on those that adopt, it is also true that institutions are "inhabited" by actors whose day-to-day behaviour sustains and alters existing orders (Hallett \& Ventresca, 2006 cited in Chandler \& Hwang, 2015). As such, organizations can be skilful at interpreting and responding to the complexity of their operating environment, leading to the conclusion that "isomorphism . . . is not a mindless, structurally determined process, but an effortful accomplishment" (Lounsbury, 2008: 353 cited in Chandler \& Hwang, 2015).

Research by Kostova and Roth (2002) examined the adoption of an organizational practice by subsidiaries of a multinational corporation. The results support the notion that there is a behavioural and attitudinal component to adoption, which is consistent with self-organisation. By hybridising the diffusion of innovations model (DIM) and complex adaptive systems theory (CAS), Rogers et al. (2005) illustrate the successful adoption of the STOP AIDS communication campaign in San Francisco. These view points lead to the hypothesis that:

\section{H3: institutional isomorphism is positively associated with self-organisation.}

H4: Self-organisation mediates the relationship between institutional isomorphism and the adoption of management controls.

\section{Research methodology}

\subsection{Research design, population, sample size}

A cross sectional survey was conducted in order to examine the relationships between institutional isomorphism, self-organisation and adoption of management controls. This method was selected because it enables collection of data from a large sample at a relatively low cost, enables generalisation and permits theory testing in 
management accounting research (Van der Stede et al., 2005) making it suitable for conducting management accounting research in LDCs (Hopper et al., 2009).

The study focused on large firms as they are more likely to have more comprehensive management controls (MCs) than smaller firms, which often use mainly informal MCs or simpler management systems (Janka et al., 2019). A single industry focus has the advantage of implicitly controlling for confounding factors as well as improving internal validity (Ittner \& Larcker, 2003). The manufacturing sector was chosen for its important contribution to Uganda's economic development, as evidenced by the fact that the manufacturing sub-sector contributes an average of 8.5\% to Gross Domestic Product (GDP) annually (MTIC, 2017), with a direct linkage to the agricultural sector, via agro-processing (Ggoobi et al., 2017).

Keeping in mind that the aim was to target large manufacturing companies, the Uganda Bureau of statistics' criteria were used to define the study's population, to include companies with an annual turnover of more than 360 million Uganda shillings (approximately $\$ 100,000$ ), and employing at least 50 persons (UBOS, 2011). The latest version of the Uganda Manufacturers Association members' register was used to construct the sampling frame. This database contained 1,221 members (UMA, 2019). A further requirement was that these companies had to be involved in direct manufacturing. Consequently, 770 met the criteria for inclusion in the sampling frame.

\subsection{Sample design and data collection procedure}

Given that the majority of Ugandan companies are not publicly traded, their financial statements were not readily available to enable a systematic random sample. Therefore, questionnaires were issued to all 770 firms in the sample. Managers were selected as key informants for two reasons. First, they were considered to be the most appropriate respondents to identify management controls in their departments. Second, given that managers are the designers of controls in organisations, it is believed that they can provide the most reliable information in regard to the controls used in their firms (Su et al., 2013). The structured questionnaires, with an introductory section explaining the objectives of the research, were personally distributed by the lead researcher and four trained research assistants.

A total of 465 responses were received, generating an initial response rate of $65.8 \%$. The returned questionnaires were checked, and firms which did not meet the criteria for large firms were discarded from the analysis. Additionally, nineteen potential respondents mentioned that their company policy prevented them from participating. Eleven of the returned questionnaires were excluded due to unsatisfactory responses. Ultimately, 202 usable questionnaires were retained, generating a final response rate of $28.6 \%$.

\subsection{Non-response bias}


If persons who respond differ substantially from those who do not, the results do not directly allow one to say how the entire sample would have responded-certainly an important step before the sample is generalized to the population (Armstrong \& Overton, 1977). Following Van der Stede et al.'s (2007 ) recommendation on how to decrease nonresponse in management accounting research, Dillman, et al.'s, (2014) tailored design method was adapted as follows; The respondents were guaranteed anonymity, the questionnaire was shortened to five pages by reducing the font size, as an incentive for participation, respondents were promised an executive summary of the study results, telephone reminders and personal visits, by the researcher, were subsequently made if the managers had not completed the questionnaire within a month of the initial request. This procedure was repeated for three months.

After data collection was complete, in order to examine for non-response bias, the responses from the first $20 \%$ of returns and those from the last $20 \%$ were compared, to test if responses differed between the two groups. The results of an independent samples t-test for each of the study variables, presented in Table 1, show no differences between the groups, providing some support for the absence of a nonresponse bias.

Table 1. Non-Response Bias Independent-Samples t-test Results

\begin{tabular}{llllcc}
\hline Variables & Group & M & SD & \multicolumn{3}{c}{ Levene's Test } \\
\hline \multirow{3}{*}{ Adoption of Management Controls } & & & & F & Sig \\
& Early & 3.7 & 0.88 & & \\
Self-Organisation & Late & 4.1 & 0.94 & 0.162 & 0.687 \\
& Early & 3.2 & 0.65 & & \\
Institutional Isomorphism & Late & 3.6 & 0.71 & 0.097 & 0.125 \\
& Early & 3.4 & 0.57 & & \\
& Late & 3.8 & 0.77 & 0.085 & 0.269 \\
\hline
\end{tabular}

\subsection{Measurement of constructs}

The measurement of constructs drew on well-established survey instruments from previous research. For measurement of the dependent variable, adoption of management controls, the conceptualisation of a package of controls suggested by Bedford et al. (2016) was employed. These categories were planning controls, cybernetic controls, reward and compensation controls, administrative controls and cultural controls.

The items were anchored on a six-point Likert type scale because, in avoiding to score the midpoint, respondents are required to deeply process each question and response option, thereby reducing response biases, and improving the validity and reliability of their responses (Kagaari et al., 2010). All the measurement items were 
reflective, as the indicators are influenced by the latent variable, and changes in the underlying latent construct are reflected by changes in the indicators. Due to the high correlations between the indicators, the indicators are also interchangeable and dropping an indicator should not alter the conceptual meaning of the construct (Bollen \& Bauldry, 2011). Thus, in this study, the measurement models that validated these indicators, and their latent variables, are known as reflective models.

Table 2. Operationalization of the study constructs

\begin{tabular}{|c|c|c|c|}
\hline Construct & Dimensions & Definition & Source \\
\hline \multirow{3}{*}{$\begin{array}{l}\text { Adoption of } \\
\text { management } \\
\text { controls }\end{array}$} & Initiation & $\begin{array}{l}\text { How management controls were } \\
\text { Identified for adoption. }\end{array}$ & $\begin{array}{l}\text { Jogaratnam and } \\
\text { Law (2006) }\end{array}$ \\
\hline & Decision & The controls adopted by the firm. & $\begin{array}{l}\text { Malmi and } \\
\text { Brown (2008); } \\
\text { Chenhall and } \\
\text { Langfield- } \\
\text { Smith, (1998) }\end{array}$ \\
\hline & Implementation & $\begin{array}{l}\text { How controls are used within the } \\
\text { company. }\end{array}$ & \\
\hline \multirow[t]{3}{*}{$\begin{array}{l}\text { Self- } \\
\text { organisation }\end{array}$} & Innovativeness & $\begin{array}{l}\text { Openness to new ideas as an aspect } \\
\text { of a firm's culture. }\end{array}$ & $\begin{array}{l}\text { Calantone } e t \\
\text { al., (2002); } \\
\text { Hurley and } \\
\text { Hult, (1998) }\end{array}$ \\
\hline & $\begin{array}{l}\text { Networks of } \\
\text { interaction }\end{array}$ & $\begin{array}{l}\text { Communication patterns which } \\
\text { exist among staff of a firm. }\end{array}$ & $\begin{array}{l}\text { Bunderson and } \\
\text { Sutcliffe, } \\
(2002) ; \text { Hoegl } \\
\text { et al., (2004) }\end{array}$ \\
\hline & Emergence & $\begin{array}{l}\text { The development of various rules, } \\
\text { customs, and standard operating } \\
\text { procedures in the firm. }\end{array}$ & $\begin{array}{l}\text { Kostova and } \\
\text { Roth }(2002)\end{array}$ \\
\hline \multirow[t]{3}{*}{$\begin{array}{l}\text { Institutional } \\
\text { isomorphism }\end{array}$} & Coercive & $\begin{array}{l}\text { Coercive was conceptualized as the } \\
\text { degree to which firms adhere to } \\
\text { guidelines provided by regulatory } \\
\text { bodies such as government agencies } \\
\text { and industrial associations. }\end{array}$ & \\
\hline & Normative & $\begin{array}{l}\text { The extent to which staff in } \\
\text { manufacturing firms adhere to a } \\
\text { code of conduct issued by } \\
\text { professional bodies. }\end{array}$ & \\
\hline & Mimetic & $\begin{array}{l}\text { The degree to which firms } \\
\text { benchmark their management } \\
\text { controls with those of } \\
\text { industry leaders, competitors, } \\
\text { industrial best practices and peers. }\end{array}$ & \\
\hline
\end{tabular}




\subsection{Instrument design and pre-test}

Previously validated measures were employed for construct measurement. However, these instruments do not necessarily remain valid in the Ugandan context, since they were borrowed from another context. Therefore, content modifications were required at the level of dimensions, item stems, and response options (Stewart et al., 2012). The initial set of questions was discussed with 9 experts in the field of accounting, who suggested improvements to some items that appeared ambiguous and double barrelled. After designing the questionnaire, five managers were asked to fill out the questionnaire. Their feedback enabled modifications to the questionnaire. A pilot study was then carried out involving 70 respondents. Based on the feedback, small adjustments to the questions, in wording or content, were made.

\subsection{Common method variance}

Common Method Variance (CMV) occurs when responses systematically vary because of the use of a common scaling approach on measures derived from a single data source, which can meaningfully distort substantively-driven causal effects (Fuller et al., Babin, 2016). To minimise this bias, considerable effort was made to ensure a well-conceived questionnaire design and data collection procedure, as elaborated above. In addition, a test was carried out for CMV in Partial Least Squares - Structural Equation Modelling (PLS-SEM) using the correlation matrix procedure (Bagozzi et al., 1991). Common method bias will be evident when a substantially large correlation is found among principal constructs $(r>0.9)$. The correlation among all the constructs was found to be less than 0.9 (see table 4). Thus, CMV is not considered an issue in this study.

\subsection{Controlling for endogeneity}

The potential for endogeneity exists in virtually all accounting studies, especially when using survey data (Peel, 2014). The study controlled for firm size and age, in the structural model, since they are shown to have a positive relationship with management controls (Davila, 2005).

\section{Data analysis and results}

The analysis of data consisted of four stages; first, the data was cleaned to see if the data contained missing values, followed a normal distribution, existence of outliers, homogeneity of variance, as well as non-linearity (Tabachnick \& Fidell, 2019). Second, descriptive statistics as well as correlations were obtained to get a feel for the data and assess whether it warranted Structural Equation Modelling (SEM), using SmartPLS v3 software (Ringle et al., 2015). The third stage involved assessment of 
validity and reliability of the measurement instrument, and finally evaluation of the structural model, to enable hypothesis testing and mediation analysis.

Empirical research in management accounting is often shaped by a complex set of different variables, often derived from theories from another research field to develop their underlying hypotheses. Testing a model that comprises general measurement constructs would generally have a high degree of goodness-of-fit (GFI) because the model would reflect some established psychological processes. However, it would not explain the specifics of management accounting in particular. This recognises the usefulness, and importance, of PLS-SEM in testing complex explorative models using specific variables to hypothesize causes and effects that are relevant to the management accounting context (Nitzl, The use of partial least squares structural equation modelling (PLS-SEM) in management accounting research: Directions for future theory development, 2016).

\subsection{Descriptive results}

Since the unit of analysis for this study is a manufacturing firm, it is important to consider the characteristics of the participating firms. $63 \%$ of the firms has been in operation for above 16 years. This is consistent with life cycle theory's argument that older firms will most likely have adopted management controls. 52\% had above 100 employees, and a turnover above 360 million Uganda shillings (approximately $100,000 \$$ ) in at least one of the previous three years. This is a reflection of the turbulent business environment in Uganda, where turnover and number of employees is not consistent over a long period of time. Also, the majority of the firms are involved in agro-processing (34\%), followed by machinery and equipment $(12 \%)$, textile and wearing apparel $(11 \%)$, which is a reflection of the strong linkage with the agricultural sector. $67 \%$ were registered as private limited companies. This confirms the minimal number of public companies in Uganda.

The characteristics of the managers indicate that $55.5 \%$ and $44.5 \%$ were male and female, respectively. This may indicate that manufacturing firms in Uganda are gender sensitive in their recruitment policy. 41\% Generation Xers, and 59\% Millennials. This mirrors the youthfulness of Africa's working age population. Over $60 \%$ had more than 5 years' job tenure. This indicates experience in implementing management controls within their firms. At least $70 \%$ had a university degree, so they could easily comprehend the questions and provide reliable responses. The distribution based on department was $16 \%$ from finance, $25 \%$ production, $23 \% \mathrm{HR} /$ Admin, 25\% sales and marketing, 10\% transport and logistics. This is an indication that most of the respondents have adequate knowledge of the management controls under investigation, since they span all departments. 
Table 3. Descriptive statistics

\begin{tabular}{llll}
\hline Sub-sector & Count & Employee No. & Count \\
\hline Agro-processing & 69 & $50-100$ & 97 \\
Furniture & 13 & Above 100 & 105 \\
\cline { 2 - 4 } Metal Products & 17 & Firm Age & Count \\
\cline { 2 - 4 } Paper Products \& Printing & 21 & $6-10$ Yrs & 45 \\
Machinery \& Equipment & 25 & $11-15$ Yrs & 29 \\
Leather \& Related Products & 10 & $16-20$ Yrs & 55 \\
Textile \& Wearing Apparel & 22 & Over 20 Yrs & 73 \\
Bricks, Cement \& Concrete & 25 & & \\
Total & $\mathbf{2 0 2}$ & & \\
\hline
\end{tabular}

\subsection{Correlation analysis}

The means, standard deviations and zero-order correlations between the study variables are presented in Table 4 . On a scale of strongly disagree (1) to strongly agree (6), the means for adoption of management controls, self-organisation and institutional isomorphism are $0.878,0.192$ and 0.483 , with standard deviations $0.020,0.072$ and 0.067 , respectively. When deviations are small compared to mean values, it is evident that the data points are close to the means, and hence, calculated means highly represent the observed data (Bagozzi, Yi, \& Phillips, 1991). The correlation analysis demonstrates that institutional isomorphism $(r=0.607, p \leq 0.01)$ and self-organisation $(\mathrm{r}=0.446, \mathrm{p} \leq 0.01)$ were significantly and positively correlated with adoption of management controls.

Table 4. Latent variable correlations

\begin{tabular}{llllllllllc}
\hline Variable & M & SD & Kurtosis & Skewness & 1. & 2. & 3. & 4. & 5. & 6. \\
\hline AMC & 0.878 & 0.020 & -0.273 & -0.522 & 1.000 & & & & & \\
S-O & 0.192 & 0.072 & -0.232 & -0.051 & 0.446 & 1.000 & & & & \\
Isomorphism & 0.483 & 0.067 & -0.808 & -0.250 & 0.607 & 0.493 & 1.000 & & & \\
Employee No. & -0.303 & 0.081 & -1.202 & -0.603 & 0.147 & 0.236 & 0.357 & 1.000 & & \\
Firm Age & -0.013 & 0.062 & -1.303 & -0.410 & 0.124 & 0.139 & 0.226 & 0.600 & 1.000 & \\
Turnover & 0.363 & 0.074 & -1.201 & -0.383 & 0.392 & 0.250 & 0.391 & 0.661 & 0.502 & 1.000 \\
\hline
\end{tabular}

Notes: Correlation is significant at the 0.01 level (2-tailed); S-O=Self-organisation, AMC=Adoption of management controls.

\subsection{Measurement model assessment}

The reflective measurement models were assessed with regard to their reliability and validity, as summarized in Table 7 (Appendix). Indicators with loadings above 0.708 were retained, as they indicate that the construct explains more than 50 per cent of the indicator's variance, thus providing acceptable item reliability. For internal consistency reliability, the Cronbach's, $\alpha$ (1951) and the composite reliability values for all the constructs lie within the recommended range of 0.7 to 0.95 , thus establishing sufficient content validity. The average variance extracted (AVE) 
values, for all the study constructs, are above 0.5 , demonstrating adequate convergent validity (Hair et al., 2019).

Discriminant validity was assessed using the heterotrait-monotrait (HTMT) ratio of the correlations (Henseler et al., 2015). The results, presented in table five, indicate that the HTMT values, for all the study constructs, are all below 0.85 , demonstrating sufficient discriminant validity.

Table 5. Heterotrait-Monotrait Ratio (HTMT) results

\begin{tabular}{llllllll}
\hline Variable & $\mathbf{1 .}$ & $\mathbf{2 .}$ & $\mathbf{3 .}$ & $\mathbf{4 .}$ & $\mathbf{5 .}$ & $\mathbf{6 .}$ \\
\hline 1. & Adoption of Management Controls & 1.00 & & & & & \\
2. & Institutional Isomorphism & 0.653 & 1.00 & & & & \\
3. & Self-Organisation & 0.488 & 0.557 & 1.00 & & & \\
4. & Employee No. & 0.156 & 0.380 & 0.251 & 1.00 & & \\
5. & Firm Age & 0.137 & 0.238 & 0.148 & 0.600 & 1.00 & \\
6. & Turnover & 0.405 & 0.417 & 0.267 & 0.661 & 0.502 & 1.00 \\
\hline
\end{tabular}

\subsection{Structural model assessment}

Following guidelines outlined in Hair et al. (2019), having established that the measurement model was satisfactory, collinearity was examined to make sure it does not bias the regression results. The results indicate that collinearity was not an issue, as the VIF values for all the study constructs are below the threshold of 3.

The next step involved assessing the model's explanatory power, by examining the $\mathrm{R} 2$ value of the endogenous construct. As a guideline, $\mathrm{R}^{2}$ values of $0.67,0.33$, or 0.19 , are described as substantial, moderate, or weak. The results, presented in table six indicate that the $\mathrm{R}^{2}$ for adoption of management controls is moderate $(0.47)$ providing support for the model's in-sample model fit.

An assessment of the $\mathrm{f}^{2}$ effect size was also carried out in order to evaluate how the removal of a certain predictor construct affects an endogenous construct's $\mathrm{R}^{2}$ value. Values of $0.02,0.15$, and 0.35 can be viewed as a gauge for whether a predictor latent variable has a weak, medium, or large effect at the structural level. Similar to the path coefficients, the results indicate that institutional isomorphism $(0.296)$ followed by self-organisation (0.0527) have the highest effect on the adoption of management controls.

Using the blindfolding procedure, Stone-Geisser's $\mathrm{Q}^{2}$ assessed the model's predictive ability. $\mathrm{Q}^{2}$ values above zero offer evidence that the observed values are well reconstructed, and that the model has predictive relevance. From the study results, presented in table six, all the values for the predictor variables are above 0 , 
institutional isomorphism (0.403), and self-organisation (0.308), further supporting the model's predictive accuracy.

Having substantiated the structural model's explanatory and predictive power, the next step was to assess the path coefficients in the structural model, in terms of sign, magnitude, and significance. This was achieved by running the nonparametric bootstrap procedure. Table six presents the direct effects as well as the bias-corrected bootstrap confidence intervals, which provide information about the size of the effect.

The results indicate that the direct relationships between institutional isomorphism $(p<0.000, \quad \beta=0.482, t-v a l u e=7.179,95 \%$ CI $[0.340,0.605])$, self-organisation $(p=0.008, \beta=0.191$, t-value $=2.641,95 \%$ CI $[0.044,0.332])$, and the adoption of management controls are all positive and significant, since the confidence intervals do not contain zero. Thus, $\mathrm{H}_{1}$ and $\mathrm{H}_{2}$ were both supported. The results also indicate that the relationships between institutional isomorphism and self-organisation $(\mathrm{p}<0.000, \beta=0.493, \mathrm{t}-\mathrm{value}=8.550,95 \% \mathrm{CI}[0.371,0.598])$ is positive and significant. Therefore, $\mathrm{H}_{3}$ was supported.

Table 6. Hypothesis tests

\begin{tabular}{|c|c|c|c|c|c|c|c|c|c|}
\hline Hypothesis & $\boldsymbol{\beta}$ & M & SD & t-value & P-value & Bias & LB & UB & Decision \\
\hline \multicolumn{10}{|l|}{ Direct effects } \\
\hline II $\rightarrow$ AMC & 0.482 & 0.483 & 0.067 & 7.179 & 0.000 & 0.002 & 0.340 & 0.605 & Supported \\
\hline II $->$ SO & 0.493 & 0.494 & 0.058 & 8.550 & 0.000 & 0.001 & 0.371 & 0.598 & Supported \\
\hline $\mathrm{SO}->\mathrm{AMC}$ & 0.191 & 0.192 & 0.072 & 2.641 & 0.008 & 0.000 & 0.044 & 0.332 & Supported \\
\hline \multicolumn{10}{|l|}{ Total effects } \\
\hline II $\rightarrow$ AMC & 0.576 & 0.578 & 0.050 & 11.456 & 0.000 & 0.002 & 0.466 & 0.664 & \\
\hline \multicolumn{10}{|l|}{ Indirect effects } \\
\hline II->SO-> AMC & 0.094 & 0.095 & 0.037 & 2.529 & 0.011 & 0.000 & 0.024 & 0.172 & Supported \\
\hline \multicolumn{10}{|c|}{ Model Quality criteria } \\
\hline & $\mathbf{f}^{2}$ & $\mathbf{Q}^{2}$ & $\mathbf{R}^{2}$ & Adj. $\mathbf{R}^{2}$ & & & & & \\
\hline$\overline{\mathrm{AMC}}$ & 1.00 & 0.489 & 0.474 & 0.461 & & & & & \\
\hline SO & 0.052 & 0.308 & & & & & & & \\
\hline II & 0.296 & 0.403 & 0.707 & 0.702 & & & & & \\
\hline
\end{tabular}

Notes: $\mathrm{AMC}=$ Adoption of Management Controls, II=Institutional Isomorphism, $\mathrm{SO}=$ Self-Organisation 
Figure 1. Structural model for the study variables

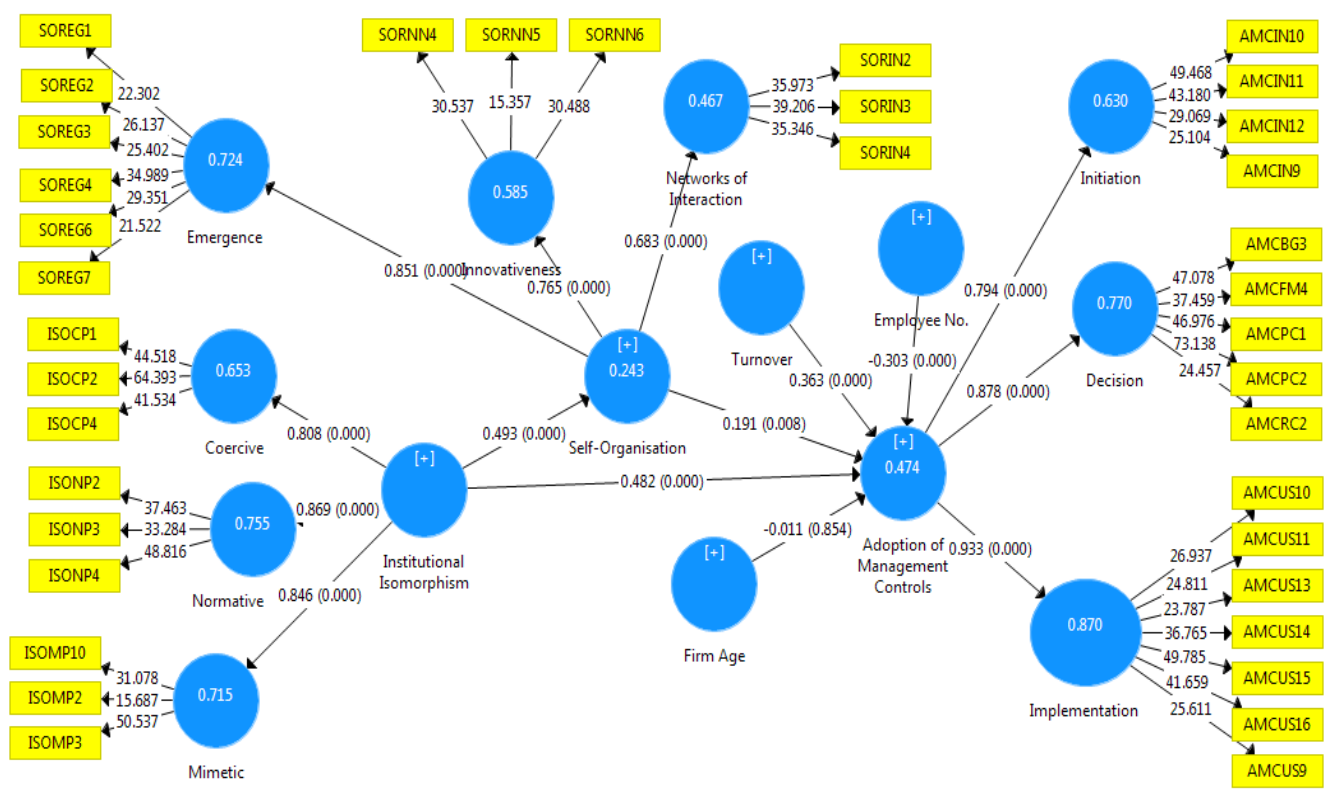

\subsection{Mediation analysis}

In order to test the indirect relationship between institutional isomorphism, selforganisation and adoption of management controls, a mediation test was deemed necessary. The core of mediation analysis is that it assumes a sequence of relationships in which an antecedent variable affects a mediating variable, which then affects a dependent variable (i.e., indirect effect or mediation) (Nitzl et al., 2016). According to Nitzl et al., (2016) three patterns are consistent with mediation. A full mediation is indicated in the case where the direct effect $c$ ' is not significant whereas the indirect effect $\mathrm{a} \times \mathrm{b}$ is significant, which means only the indirect effect via the mediator exists. In other words, full mediations means that the effect of the variable $\mathrm{X}$ to $\mathrm{Y}$ is completely transmitted with help of another variable $\mathrm{M}$. It also means the condition $\mathrm{Y}$ completely absorbs the positive or negative effect of $\mathrm{X}$. In this way, it can completely pass an effect or it can completely hinder the effect in terms of another effect. All other situations under the condition that both the direct effect $c^{\prime}$ and the indirect effect $\mathrm{a} \times \mathrm{b}$ are significant represent partial mediation. Two types of partial mediations can be distinguished: a complementary partial mediation, the direct effect $\mathrm{c}^{\prime}$ and indirect effect $\mathrm{a} \times \mathrm{b}$ point in the same (positive or negative) direction, and a competitive partial mediation, where the direct effect c' and indirect effect $\mathrm{a} \times \mathrm{b}$ point in a different direction. Finally, If the indirect effect $\mathrm{a} \times \mathrm{b}$ is not significant, whereas the direct path c' is, the mediator variable has no impact; this indicates that a direct, non-mediating effect is present. 
Zhao et al. (2010) further advise that, contrary to the guidelines of Baron and Kenny (1986), in order to establish mediation, all that matters is that the indirect effect is significant. Therefore, the Baron- Kenny "three tests + Sobel" steps be replaced with one and only one test: the bootstrap test of the indirect effect $\mathrm{a} x \mathrm{~b}$, as opposed to Sobel's z-test, because it estimates everything simultaneously, instead of assuming that the equations are independent.

The 95\% bias-corrected and accelerated (BCa) bootstrap confidence intervals, No Sign Change option, with 10,000 samples, was used to assess the significance of the path coefficients in the structural model, since it's the best approach for detecting mediation effects, in PLS-SEM, when a mediation effect is present (i.e., Type II error or power) (Streukens \& Leroi-Werelds, 2016).

The results indicate that the indirect effect of the relationship between institutional isomorphism, self-organisation and adoption of management controls is positive and significant, since the confidence interval doesn't include zero $(\beta=0.094, p=0.011$, $\mathrm{t}$-value $=2.529,95 \%$ CI $[0.024,0.172])$. At the same time, the direct effect from institutional isomorphism to adoption of management controls, is also positive and significant $(\mathrm{p}<0.000, \beta=0.482$, $\mathrm{t}$-value $=7.179,95 \%$ CI $[0.340,00.605])$, confirming the partial mediation of self-organisation in the relationship between institutional isomorphism and adoption of management controls. Therefore, $\mathrm{H} 4$ was supported. The total effect is also positive (i.e., $0.493 * 0.191=0.094$ ). Therefore, selforganisation represents complementary partial mediation of the relationship between institutional isomorphism and adoption of management controls.

\section{Discussion and conclusions}

\subsection{Discussion of findings}

The purpose of this study was to examine whether self-organisation mediates the relationship between institutional isomorphism and adoption of management controls, in manufacturing firms. Four hypotheses were derived from the literature review, tested and confirmed.

The results confirm a positive and significant relationship between institutional isomorphism and the adoption of management controls. This underscores the influence of professional bodies, like the Institute of Certified Public Accountants, regulators such as Uganda Manufacturers Association, and competitors in shaping the behaviours of manufacturing firms. Since managers adopt the practices recommended by their professional bodies, they will recommend that such practices be adopted by the firm that employs them. Additionally, responding to demands from regulatory agencies has led many manufacturing firms to adopt practices, such as environmental management accounting, within their management controls. These 
findings are consistent with Greenwood et al. (2002) who confirmed the influence of isomorphic pressure on an accounting firm, which led to the firm adopting the practices recommended by the accounting body. Bananuka et al. (2019) also find that institutional isomorphic forces are positively associated with the adoption of International Financial Reporting Standards (IFRS) in Microfinance Institutions.

The results also indicate that the relationship between self-organisation and adoption of management controls is positive and significant. Therefore, managers should encourage their staff to take risks, while being supportive and tolerant of mistakes. This will enable the staff, and management, to identify with the adopted management controls. This will be demonstrated by their effort in using these controls to plan how operations are to be conducted, communicate the company's core values to the staff, track progress towards goals and monitor results. This finding is supported by Omeke et al. (2019) who find that managers interact, exchange, and share information, in order to become aware of problems and opportunities within their business environments. Bourne (2014) argued that the process of adopting management controls is critical, as it engages management and builds their commitment to the implementation of the management controls.

A positive relationship was established between institutional isomorphism and selforganisation. This suggests that staff in the manufacturing firms are able to mutually adjust their behaviours in order to cope with isomorphic pressure from the external environment. This is possible because management enables an environment where innovativeness is encouraged and rewarded, instead of being punished, staff members are motivated to continuously interact and share ideas, and develop a value system that acts as a rudder to guide organisation members. These findings correspond with those of Mutebi et al. (2020) who underscore the importance of selforganisation in helping to increase the flexibility of an organisation, so as to deliver its mandate in a timely manner, when working with others in the delivery of relief services to the beneficiaries. The implication of this finding is that self-organisation can enable an organisation to generate its own management controls from inner guidelines, rather than from external imposition, in order to cope with its environment (Cilliers, 1998). Further to this, it has been noted that organisations impact the environment via management activities, such as management controls. they shape people's behaviour by limiting behavioural options and at the same time enabling the pursuit of (possibly new) behaviours.

As outlined above, co-evolutionary interactions between individual behaviours and institutions are mainly channelled via knowledge, norms and values which bridge the collective outcomes of far from equilibrium interactions and heterogeneous learning at the behavioural level with the established mechanisms at the institutional level that shape, constraint and initiate low-level behaviour (Rammel et al., 2007). These systems are particularly robust, because they adapt to these changes, and are able to ensure their own survivability. These internal processes are the networks of 
interaction, innovativeness and emergence, characterised in self-organisation. This line of reasoning is similar to that advanced by Walby (2007) who contends that since an organisations environment is composed of other organisations(systems), these other systems also change internally. Since each system has an internal system, any initial impact will have complex effects upon the internal relations of the other system. In this case the mutual modifications of the systems as they interact does not lead to the loss of the identity of each system.

The results confirm that self-organisation partially mediates the relationship between institutional isomorphism and the adoption of management controls. Higher levels of institutional isomorphism lead to the adoption of management controls directly but also increase self-organisation, which in turn leads to the adoption of management controls. Hence, some of institutional isomorphism's effect on the adoption of management controls is explained by self-organisation. This implies that institutional isomorphic pressures alone may not influence the adoption of management controls effectively, unless there are internal mechanisms to support them. This finding is supported by O'Connor et al. (2004) whose study on the adoption of 'Western' management controls in China's state-owned enterprises during economic transition, found that such practices can be influenced by external forces and parties, as well as attributes of the organization and its individual constituents. In addition, Mutebi et al.'s (2020) study findings that self-organisation can mediate the relationship between adaptability and inter-organisation coordination, implies that an organisation that adjusts its priorities to meet the needs of its beneficiaries can more effectively prepare for its future operations.

Relatedly, organisations that have the ability to change their functions to successfully perform a task encourage their employees to think and come up with creative solutions through which they are able to deliver on their mandate in time. This is because, for an organisation to change its functions to successfully perform a task, it becomes incumbent upon the employees to think and rethink within their own jurisdiction the other possible ways through which to execute their own work if they are to deliver on time.

\subsection{Conclusions}

The aim of this study was to establish whether self-organisation mediates the relationship between institutional isomorphism and adoption of management controls. This was based on the argument that external practices do not just enter an organisation, but are affected by internal organisation dynamics. Based on a theoretical model that draws from institutional and complexity theories, the empirical findings in support of the hypothesised relationships corroborate the theoretical assertion that self-organisation mediates the relationship between institutional isomorphism and adoption of management controls. 
Additionally, this study concludes that institutional isomorphism and selforganisation are important enablers of adoption of management controls. The current study contributes to the existing knowledge by offering significant information about institutional isomorphism, self-organisation and adoption of management controls, which is presently lacking.

\subsection{Implications}

The results of this study have important implications for both, the academic community and managers, regarding the adoption of management controls.

For academics, the results suggest that both institutional isomorphic forces, and selforganisation contribute greatly to the adoption of management controls, especially when self-organisation mediates this process. Therefore, studies on adoption of management controls utilizing institutional and complexity theories should be aware of this.

From a practical point of view, if manufacturing firms are interested in the adoption of management controls, they should adhere to the norms in the manufacturing sector. These expected behaviours will enable managers to reduce uncertainty regarding how to conduct their operations, since they are adopting practices which have been successfully employed by other firms.

In the same line, if the Institute of Certified Public Accountants of Uganda, which is the professional accountancy body in the country, continuously encourages adherence to professionalism by their members working in manufacturing firms, the adoption of management controls will be enhanced. This is because professionalism implies sharpening one's accounting skills and knowledge, and keeping abreast of trends in the accounting profession. This is achieved through Continuous Professional Development seminars. The knowledge gained from these seminars is then transferred to the manufacturing firms, in form of up-to-date information and recommendations on new management controls.

From a regulatory perspective, should Uganda Manufacturers Association, as an industry trade association, require its members to adopt management controls specific to the manufacturing sector, such as such as Kaizen, or continuous improvement, Total Quality Management (TQM), Just-In-time (JIT) manufacturing, and International Standards Organisation (ISO) Certification, managers are likely to adhere to such controls. This will in turn lead to improved performance on account of efficiency in operations.

Of equal importance, managers should openly share information, with fellow managers and staff, since information sharing activities enable the staff buy into the 
proposed solutions, which they will identify with, and be committed to implementing.

\subsection{Limitations and directions for future research}

As with a quantitative cross-sectional study, the results are subject to a number of limitations, including potential response biases, endogeneity of the predictor variables, model specification, and the difficulty in using a survey instrument to obtain factual, detailed information on exactly how firms adopt management controls (Podsakoff et al., 2012). In addition, the results may not generalize to other industries or competitive settings.

Having established the general trend, there is a need to study in more detail, through case studies, the adoption of these management controls. Other interesting opportunities for research, in this area, lie in performing a more specific industry analysis (for instance, the agro-processing sub-sector due to its significant linkage with the agricultural sector). The same applies to firm size. A detailed analysis of both large and small firms would make it possible to see whether significant differences exist between them regarding the adoption of management controls.

\section{References}

Abdelnour, S., Hasselbladh, H., \& Kallinikos, J. (2017) "Agency and institutions in organization studies", Organization Studies, vol. 38, no. 12: 1775-1792

Anderson, P. (1999) "Perspective: Complexity theory and organization science", Organization Science, vol.10, no. 3: 216-232

Anzola, D., Barbrook-Johnson, P., \& Cano, J. I. (2017) "Self-organization and social science", Computational and Mathematical Organization Theory, vol. 23: 221-257

Armstrong, S. J., \& Overton, T. S. (1977) "Estimating nonresponse bias in mail surveys" Journal of Marketing Research, vol.14, no. 3: 396-402

Ax, C., \& Greve, J. (2017) "Adoption of management accounting innovations: Organizational culture, compatibility and perceived outcomes", Management Accounting Research, vol. 34: 59-74

Bagozzi, R. P., Yi, Y., \& Phillips, L. W. (1991) "Assessing construct validity in organizational research", Administrative Science Quarterly, vol. 36, no. 3: 421-458

Bananuka, J., Tumwebaze, Z., Musimenta, D., \& Nuwagaba, P. (2019) "Determinants of adoption of International Financial Reporting Standards in Ugandan micro finance institutions", African Journal of Economic and Management Studies, vol.10, no.6: 336-355 
Battilana, J., Leca, B., \& Boxenbaum, E. (2009) "How actors change institutions: towards a theory of institutional entrepreneurship", The Academy of Management Annals, vol.3, no.1: 65-107

Bedford, D. S., \& Malmi, T. (2015) "Configurations of control: An exploratory analysis", Management Accounting Research, vol. 27: 2-26

Bedford, D. S., \& Sandelin, M. (2016) "Management control effectiveness and strategy: An empirical analysis of packages and systems" Accounting, Organizations and Society, vol. 51: 12-28

Beunen, R., \& Patterson, J. (2019) "Analysing institutional change in environmental governance: exploring the concept of 'institutional work'", Journal of Environmental Planning and Management, vol. 62: 12-29

Boisot, M., \& McKelvey, B. (2011) "Complexity and organization-environment relations: Revisiting Ashby's law of requisite variety", In The Sage Handbook of Complexity and Management, pp. 278-298, SAGE Publications Ltd

Bollen, K. A., \& Bauldry, S. (2011) "Three Cs in measurement models: causal indicators, composite indicators, and covariates", Psychological Methods, vol.16, no. 3: 265-284

Bourne, M. (2014) "Managing through uncertainty", In S. K. Otley D. (Ed.), Management Control and Uncertainty, pp. 97-113, London: Palgrave Macmillan

Bourne, M., Franco-Santos, M., Micheli, P., \& Pavlov, A. (2018) "Performance measurement and management: A system of systems perspective", International Journal of Production Research, vol. 56, no. 8: 2788-2799

Braithwaite, J., Churruca, K., Long, J. C., Ellis, L. A., \& Herkes, J. (2018) "When complexity science meets implementation science: a theoretical and empirical analysis of systems change" BMC Medicine, vol.16, no: 63

Bunderson, J. S., \& Sutcliffe, K. M. (2002) "Comparing alternative conceptualizations of functional diversity in management teams:process and performance effects" The Academy of Management Journal, vol. 45, no. 5: 875-893

Calantone, R. J., Cavusgil, S. T., \& Zhao, Y. (2002) "Learning orientation, firm innovation capability, and firm performance", Industrial Marketing Management, vol. 31, no. 6: 515-524

Chandler, D., \& Hwang, H. (2015) "Learning from learning theory: a model of organizational adoption strategies at the microfoundations of institutional theory", Journal of Management, vol. 41, no. 5: 1-31

Chenhall, R. H., \& Langfield-Smith, K. (1998) "Adoption and benefits of management accounting practices: an Australian study", Management Accounting Research, vol. 9, no. 1: 1-19

Cilliers, P. (1998) Complexity and postmodernism: understanding complex systems, London: Routledge

Damanpour, F., \& Aravind, D. (2012) "Managerial innovation: conceptions, processes, and antecedents", Management and Organization Review, vol. 8, no.2: $423-454$ 
Davila, T. (2005) "An exploratory study on the emergence of management control systems: formalizing human resources in small growing firms", Accounting, Organizations and Society, vol.30, no.3: 223-248

De Prá Carvalho, A., Kindl da Cunha, S., Ferreira de Lima, L., \& Carstens, D. D. (2017) "The role and contributions of sociological institutional theory to the socio-technical approach to innovation theory", RAI Revistade Administração e Inovação, vol.14, no.3: 250-259

Dick, P., Faems, D., \& Harley, B. (2017) "An introduction to the special issue on managing complexity within and across organizational boundaries" Journal of Management Studies, vol. 54, no.2: 129-131

Dillman, D. A., Smyth, J. D., \& Christian, L. M. (2014) Internet, phone, mail and mixed-mode surveys: The tailored design, (4th ed.), Hoboken: NJ: John Wiley Co

DiMaggio, P. J., \& Powell, W. W. (1983) "The iron cage revisited: Institutional isomorphism and collective rationality in organization fields", American Sociological Review, vol. 48, no. 2: 147-160

Dooley, K. J. (1997) "A complex adaptive systems model of organization change" Nonlinear Dynamics, Psychology, and Life Sciences, vol.1, no.1: 69-97

Dosi, G., Marengo, L., \& Nuvolari, A. (2019) "Institutions and economic change: some notes on self organization, power and learning in human organizations", Eurasian Business Review, vol.10, no.1: (22 pages)

Du, J., \& Zhou, C. (2019) "Does guanxi matter in the foreign expansion of Chinese manufacturing firms? The mediator role of linking and leveraging", Asia Pacific Journal of Management, vol.36, no.2: 473-497

Erokhin, V., Endovitsky, D., Bobryshev, A., Kulagina, N., \& Ivolga, A. (2019) "Management accounting change as a sustainable economic development strategy during pre-recession and recession periods: evidence from Russia", Sustainability, vol. 11, no.11: 1-23

Fuller, C. M., Simmering, M. J., Atinc, G., Atinc, Y., \& Babin, B. J. (2016) "Common methods variance detection in business research", Journal of Business Research, vol. 69, no. 8: 3192-3198

Garud, R., Hardy, C., \& Maguire, S. (2007) "Institutional entrepreneurship as embedded agency: An introduction to the special issue", Organization Studies, vol. 28, no.7: 957-969

Gazizulina, A., Eskina, E., Vasilieva, I., \& Valeeva, O. (2017) "The reasons for the increase in self-organization in companies", International Journal of Reliability, Quality and Safety Engineering, vol. 24, no.6: (11 pages)

Ggoobi, R., Wabukala, B. M., \& Ntayi, J. (2017) Economic development and industrial policy in Uganda, Kampala: Friedrich-Ebert-Stiftung

Greenwood, R., Raynard, M., Kodeih, F., Micelotta, E., \& Lounsbury, M. (2011) "Institutional complexity and organizational responses", The Academy of Management Annals, vol. 5, no.1: 317-371 
Hair, J. F., Risher, J. J., Sarstedt, M., \& Ringle, C. M. (2019) "When to use and how to report the results of PLS-SEM", European Business Review, vol. 31, no. 1: 2-24

Hassas, S., Di Marzo-Serugendo, G., Karageorgos, A., \& Castelfranchi, C. (2006) "On self-organising mechanisms from social, business and economic domains", Informatica, vol. 30, no. 1: 63-71

Henseler, J., Ringle, C. M., \& Sarstedt, M. (2015) "A new criterion for assessing discriminant validity in variance-based structural equation modelling", Journal of the Academy of Marketing Science, vol. 43, no. 1: 115-135

Hopper, T., Tsamenyi, M., Uddin, S., \& Wickramasinghe, D. (2009) "Management accounting in less developed countries: what is known and needs knowing", Accounting, Auditing \& Accountability Journal, vol. 22, no. 3: 469-514

Hult, T., Hurley, R. F., \& Knight, G. A. (2004) "Innovativeness: Its antecedents and impact on business performance", Industrial Marketing Management, vol. 33, no. 5: 429-438

Iredele, O. O., Tankiso, M., \& Adelowotan, M. O. (2019) "The influence of institutional isomorphism and organisational factors on environmental management accounting practices of listed Nigerian and South African firms", South African Journal of Accounting Research, vol. 34, no. 3:183-204

Ittner, C., \& Larcker, D. (2003) "Performance implications of strategic performance measurement in financial services firms", Accounting, Organizations and Society, vol. 28, no. 7-8:715-741

Janka, M., Heinicke, X., \& Guenther, T. W. (2019) "Beyond the "good" and "evil" of stability values in organizational culture for managerial innovation: the crucial role of management controls", Review of Managerial Science, vol. 14, no. 6: 1363-1404

Jogaratnam, G., \& Law, R. (2006) "Environmental scanning and information source utilization: exploring the behavior of Hong Kong hotel and tourism executives", Journal of Hospitality \& Tourism Research, vol. 30, no. 2: $170-190$

Jung, K. B., Kang, S.-W., \& Choi, S. B. (2020) "Empowering leadership, risk-taking behavior, and employees' commitment to organizational change: the mediated moderating role of task complexity", Sustainability, vol.12, no.6: 1-18

Kagaari, J. R., Munene, J. C., \& Ntayi, J. M. (2010) "Performance management practices, information and communication technology (ICT) adoption and managed performance", Quality Assurance in Education, vol. 12, no. 2: 106-125

Kontinen, T., \& Onali, A. (2017) "Strengthening institutional isomorphism in development NGOs? program mechanisms in an organizational intervention", SAGE Open, vol. 7, no. 1:1-14

Kostova, T., \& Roth, K. (2002) "Adoption of an organizational practice by subsidiaries of multinational corporations: Institutional and relational effects" The Academy of Management Journal, vol. 45, no. 1: 215-233 
Leeuwis, C., \& Aarts, N. (2011) "Rethinking communication in innovation processes: creating space for change in complex systems", The Journal of Agricultural Education and Extension, vol. 17, no. 1: 21-36

Malek, S., Sarin, S., \& Jaworski, B. (2018) "Sales management control systems: review, synthesis, and directions for future exploration", Journal of Personal Selling \& Sales Management, vol. 38, no. 1:1-26

Malmi, T. (2013) "Management control as a package-The need for international research", Journal of Management Control, vol. 23, no. 4: 229-231

Malmi, T., \& Brown, D. (2008) "Management control systems as a packageOpportunities, challenges and research directions", Management Accounting Research, vol. 19, no. 4: 287-300

Meyer, J. W., \& Rowan, B. (1977) "Institutionalized organizations: formal structure as myth and ceremony", American Journal of Sociology, vol. 83, no. 2: 340-363

Meyer, J. W., \& Scott, W. R. (1991) Organizational Environments: Ritual and Rationality (updated edition), Newbury Park, CA: Sage

Mir, M., \& Rahaman, A. S. (2002) "The adoption of international accounting standards in Bangladesh: An exploration of rationale and process", Accounting, Auditing \& Accountability Journal, vol. 18, no. 6: 816-841

Mohammed, A. M. (2010) An exploratory study of management accounting and control systems in a developing country, PHD thesis, Aston University

MTIC. (2017) Trade and Industry Sector Statistical Abstract (SSA) 2017/18, Kampala: Ministry of Trade, Industry and Cooperatives, Republic of Uganda

Munir, R., Perera, S., \& Baird, K. (2011) "An Analytical Framework to Examine Changes in Performance Measurement Systems within the Banking Sector", Australasian Accounting, Business and Finance Journal, vol. 5, no. 1: 93-115

Musimenta, D., Nkundabanyanga, S. K., Muhwezi, M., Akankunda, B., \& Nalukenge, I. (2017) "Tax compliance of small and medium enterprises: a developing country perspective", Journal of Financial Regulation and Compliance, vol. 25, no. 2: 149-175

Mutebi, H., Muhwezi, M., Ntayi, J. M., \& Munene, J. C. (2020) "Organisation size, innovativeness, self-organisation and inter-organisational coordination", International Journal of Emergency Services, vol. 9, no. 3:359-394

Mutebi, H., Ntayi, J. M., Muhwezi, M., \& Munene, J. C. (2020) "Self-organisation, adaptability, organisational networks and inter-organisational coordination: empirical evidence from humanitarian organisations in Uganda", Journal of Humanitarian Logistics and Supply Chain Management, vol. 10, no. 4: 447-483

Namakonzi, R., \& Inanga, E. (2014) "Environmental management accounting and environmental management in manufacturing industries in Uganda", Working Paper No. 2014/39

Nan, N., Zmud, R., \& Yetgin, E. (2014) "A complex adaptive systems perspective of innovation diffusion: an integrated theory and validated virtual laboratory", Computational and Mathematical Organization Theory, vol. 20, no. 1: 52-88 
Nitzl, C. (2016) "The use of partial least squares structural equation modelling (PLSSEM) in management accounting research: Directions for future theory development, Journal of Accounting Literature, vol. 37: 19-35

Nitzl, C., Roldan, J. L., \& Cepeda, G. (2016) "Mediation analysis in partial least squares path modelling: helping researchers discuss more sophisticated models", Industrial Management \& Data Systems, vol. 116, no. 9: 1849-1864

Nkundabanyanga, S. K., Muhwezi, M., \& Tauringana, V. (2018) "Management accounting practices, governing boards and competitive advantage of Ugandan secondary schools", International Journal of Educational Management, vol. 32, no. 6: 958-974

Nkundabanyanga, S. K., Mvura, P., Nyamuyonjo, D., Opiso, J., \& Nakabuye, Z. (2017) "Tax compliance in a developing country: Understanding taxpayers' compliance decision by their perceptions", Journal of Economic Studies, vol. 44, no. 6: 931-957

O'Connor, N. G., Chow, C. W., \& Wu, A. (2004) "The adoption of "Western" management accounting/controls in China's state-owned enterprises during economic transition", Accounting, Organizations and Society, vol. 29, no. 3-4: 349-375

Oerlemans, L., Meeus, M., \& Kenis, P. (2007) "Regional innovation networks", In R. R. (ed.), The Learning Region, chapter 8, Edward Elgar Publishing

Omeke, M., Ngoboka, P. T., Nkote, N. I., \& Kayongo, I. (2019) "The relationship between complexity behavior and enterprise growth: A case of savings and credit cooperatives in Uganda", Cogent Business \& Management, vol. 6, no. 1: 1564421

Peel, M. J. (2014) "Addressing unobserved endogeneity bias in accounting studies: control and sensitivity methods by variable type", Accounting and Business Research, vol. 44, no. 5: 545-571

Podsakoff, P. M., MacKenzie, S. B., \& Podsakoff, N. P. (2012) "Sources of method bias in social science research and recommendations on how to control it", Annual Review of Psychology, vol. 63, 539-569

Poutanen, P., Soliman, W., \& Ståhle, P. (2016) "The complexity of innovation: An assessment and review of the complexity perspective", European Journal of Innovation Management, vol. 19, no. 2: 189-213

Preiser, R., Biggs, R., De Vos, A., \& Folke, C. (2018) "Social-ecological systems as complex adaptive systems: Organizing principles for advancing research methods and approaches", Ecology and Society, vol. 23, no. 4: 46

Rammel, C., Stagl, S., \& Wilfing, H. (2007) "Managing complex adaptive systems - A co-evolutionary perspective on natural resource management", Ecological Economics, vol. 6, no. 3: 9-21

Ringle, C. M., Wende, S., \& Becker, J.-M. (2015) "SmartPLS 3. Bönningstedt: SmartPLS", Retrieved from http://www.smartpls.com

Rogers, E. (2010) "Diffusion of Innovations", New York, N. Y.: Simon and Schuster 
Rogers, E. M., Medina, U. E., Rivera, M. A., \& Wiley, C. J. (2005) "Complex adaptive systems and the diffusion of innovations", The Innovation Journal: The Public Sector Innovation Journal, vol. 10, no. 3: article 29

Room, G. (2011) "Complexity, Institutions and Public Policy", Cheltenham: Edward Elgar

Roszkowska-Menkes, M., \& Aluchna, M. (2017) "Institutional isomorphism and corporate social responsibility: towards a conceptual model", Journal of Positive Management, vol. 8, no. 2: 3-16

Sadress, N., \& Bananuka, J. (2019) "The mediating role of adoption of an electronic tax system in the relationship between attitude towards electronic tax system and tax compliance", Journal of Economics, Finance and Administrative Science, vol. 25, no. 49: 73-88

Scott, W. R. (1995) "Institutions and Organizations", Thousand Oaks: SAGE Publications

Serugendo, G. D., Foukia, N., Hassas, S., Karageorgos, A., Most'efaoui, S. K., Rana, O. F., Van Aart, C. (2004) "Self-Organisation: Paradigms and Applications" In G. D. (Eds.), AAMAS 2003 Ws ESOA, LNAI 2977, 1-19, Springer-Verlag Berlin Heidelberg

Serugendo, G. D., Gleizes, M.-P., \& Karageorgos, A. (2006) "Self-Organisation and Emergence in MAS: An Overview", Informatica, vol. 30, no. 1: 45-54

Simons, R. (2010) "Seven strategy questions: A simple approach for better execution", Harvard: Business Review Press

Smith, A. C. (2005) "Complexity theory for organisational futures studies", Foresight, vol. 7, no. 3: 22-30

Soobaroyen, T., Tsamenyi, M., \& Sapra, H. (2017) "Accounting and governance in africa - contributions and opportunities for further research", Journal of Accounting in Emerging Economies, vol. 7, no. 4: 422-427

Speklé, R., \& Kruis, A.-M. (2014) "Management Control Research: A Review of Current Developments", In S. K. Otley D. (Ed.), Management Control and Uncertainty, 30-46, London: Palgrave Macmillan

Stewart, A. L., Thrasher, A. D., Goldberg, J., \& Shea, J. A. (2012) "A framework for understanding modifications to measures for diverse populations", Journal of Aging and Health, vol. 24, no. 6: 992-1017

Streukens, S., \& Leroi-Werelds, S. (2016) "Bootstrapping and PLS-SEM: A stepby-step guide to get more out of your bootstrap results", European Management Journal, vol. 34, no. 6: 618-632

$\mathrm{Su}$, S., Baird, K., \& Schoch, H. (2013) "Management control systems from an organisational life cycle perspective: The role of input, behaviour and output controls", Journal of Management \& Organization, vol. 19, no. 05: 635-658

Tabachnick, B. G., \& Fidell, L. S. (2019) "Using Multivariate Statistics", 7th Edition, Boston: Pearson

Tenbensel, T. (2013) "Introduction: Complexity in health and healthcare systems", Social Science \& Medicine, vol. 93, 181-184 
Thrane, S., \& Leitner, K.-H. (2010) "Management control in complex innovation and inter-organisational systems: Controlled stability or facilitated selforganisation?", Working Paper

Tracey, P., Phillips, N., \& Jarvis, O. (2011) "Bridging institutional entrepreneurship and the creation of new organizational forms: A multilevel model", Organization Science, vol. 22, no. 1: 60-80

UBOS. (2011) "Uganda Bureau of Statistics Report on the Census of Business Establishments, 2010/11", Kampala, Uganda: Uganda Bureau of Statistics

UMA. (2019) "Uganda Manufacturers' Association Membership Database", https://www.uma.or.ug

Van der Stede, W. A., Young, S. M., \& Chen, C. X. (2005) "Assessing the quality of evidence in empirical management accounting research: The case of survey studies", Accounting, Organizations and Society, vol. 30, no:7-8: 655-684

Walby, S. (2007) "Complexity theory, systems theory, and multiple intersecting social inequalities", Philosophy of the Social Sciences, vol. 37, no. 4: 449-470

Zhao, E. Y., Fisher, G., Lounsbury, M., \& Miller, D. (2017) "Optimal distinctiveness: Broadening the interface between institutional theory and strategic management", Strategic Management Journal, vol. 38, no.1: 93-113

Zhao, X., Lynch Jr., J. G., \& Chen, Q. (2010) "Reconsidering Baron and Kenny: Myths and Truths about Mediation Analysis", Journal of Consumer Research, vol. 37, no. 2: 197-206 


\section{Appendix}

Table 7. Reliability and validity values for the study constructs

\begin{tabular}{|c|c|c|c|c|}
\hline Construct & Loading & $\alpha$ & $\mathbf{C R}$ & AVE \\
\hline Adoption of Management Controls & & 0.94 & 0.95 & 0.55 \\
\hline Initiation & & 0.91 & 0.93 & 0.78 \\
\hline Consultants & 0.877 & & & \\
\hline Fellow Managers & 0.906 & & & \\
\hline Internal reports & 0.900 & & & \\
\hline Other Staff in the company & 0.868 & & & \\
\hline Decision & & 0.91 & $\mathbf{0 . 9 3}$ & 0.73 \\
\hline Strategic plan & 0.891 & & & \\
\hline Operational plan & 0.905 & & & \\
\hline Forecasting & 0.883 & & & \\
\hline Discounted cash flow & 0.830 & & & \\
\hline Bonuses & 0.883 & & & \\
\hline Implementation & & 0.91 & $\mathbf{0 . 9 3}$ & 0.66 \\
\hline $\begin{array}{l}\text { Management controls are used to track progress } \\
\text { towards goals. }\end{array}$ & 0.774 & & & \\
\hline Management controls are used to monitor results. & 0.802 & & & \\
\hline $\begin{array}{l}\text { Management controls are used to plan how operations } \\
\text { are to be conducted. }\end{array}$ & 0.791 & & & \\
\hline $\begin{array}{l}\text { Management controls are used to identify significant } \\
\text { exceptions from expectations. }\end{array}$ & 0.773 & & & \\
\hline $\begin{array}{l}\text { Management controls are often used as a means of } \\
\text { identifying strategic uncertainties. }\end{array}$ & 0.837 & & & \\
\hline $\begin{array}{l}\text { Management controls are often used as a means of } \\
\text { developing ongoing action plans. }\end{array}$ & 0.863 & & & \\
\hline $\begin{array}{l}\text { Management controls generate information that forms } \\
\text { an important agenda in management meetings. }\end{array}$ & 0.850 & & & \\
\hline Self-Organisation & & 0.86 & $\mathbf{0 . 8 9}$ & 0.40 \\
\hline Innovativeness & & $\mathbf{0 . 7 0}$ & $\mathbf{0 . 8 3}$ & 0.63 \\
\hline $\begin{array}{l}\text { Our company is often the first to market with new } \\
\text { products. }\end{array}$ & 0.827 & & & \\
\hline $\begin{array}{l}\text { Innovation in our company is perceived as too risky } \\
\text { and is resisted }(\mathrm{R}) \text {. }\end{array}$ & 0.742 & & & \\
\hline $\begin{array}{l}\text { Our company's new product introduction has increased } \\
\text { over the last } 5 \text { years. }\end{array}$ & 0.813 & & & \\
\hline Networks of Interaction & & $\mathbf{0 . 8 2}$ & $\mathbf{0 . 8 9}$ & 0.74 \\
\hline $\begin{array}{l}\text { I communicate intensively with other managers, in this } \\
\text { company. }\end{array}$ & 0.857 & & & \\
\hline $\begin{array}{l}\text { I openly share information, with other managers, in this } \\
\text { company. }\end{array}$ & 0.890 & & & \\
\hline $\begin{array}{l}\text { I receive timely information from other managers, in } \\
\text { this company. }\end{array}$ & 0.843 & & & \\
\hline Emergence & & 0.87 & 0.90 & 0.62 \\
\hline
\end{tabular}

Vol. 20, No. 2 


\begin{tabular}{|c|c|c|c|c|}
\hline Construct & Loading & $\alpha$ & $\mathbf{C R}$ & AVE \\
\hline $\begin{array}{l}\text { I have observed new management controls emerging in } \\
\text { this company. }\end{array}$ & 0.762 & & & \\
\hline $\begin{array}{l}\text { I am willing to put in a great deal of effort to } \\
\text { implement these new management controls. }\end{array}$ & 0.789 & & & \\
\hline I talk up these new management controls to staff. & 0.785 & & & \\
\hline $\begin{array}{l}\text { I find that my values and the values promoted by these } \\
\text { new management controls are very similar. }\end{array}$ & 0.827 & & & \\
\hline $\begin{array}{l}\text { I am extremely glad that I am involved in } \\
\text { implementing these new management controls. }\end{array}$ & 0.818 & & & \\
\hline $\begin{array}{l}\text { I really care about these new management controls and } \\
\text { their future. }\end{array}$ & 0.756 & & & \\
\hline Institutional Isomorphism & & 0.88 & 0.90 & 0.51 \\
\hline Coercive & & 0.87 & 0.92 & $\mathbf{0 . 7 9}$ \\
\hline $\begin{array}{l}\text { This company observes the provisions of the Code of } \\
\text { Corporate Governance issued by Institute of Corporate } \\
\text { Governance. }\end{array}$ & 0.878 & & & \\
\hline $\begin{array}{l}\text { Social non-governmental agencies usually request this } \\
\text { company to provide them with certain information on } \\
\text { the environment. }\end{array}$ & 0.919 & & & \\
\hline $\begin{array}{l}\text { Our company considers sanctions by professional } \\
\text { bodies, such as Institute of Certified Public }\end{array}$ & 0.882 & & & \\
\hline Accountants, on its staff members seriously. & & & & \\
\hline Normative & & $\mathbf{0 . 8 3}$ & $\mathbf{0 . 8 9}$ & 0.74 \\
\hline $\begin{array}{l}\text { Uganda Manufacturers Association emphasizes } \\
\text { adherence to professionalism. }\end{array}$ & 0.852 & & & \\
\hline $\begin{array}{l}\text { Staff of this company believe in the principle of } \\
\text { objectivity. }\end{array}$ & 0.872 & & & \\
\hline $\begin{array}{l}\text { Staff of this company adhere to professional codes of } \\
\text { ethics set up by professional bodies. }\end{array}$ & 0.870 & & & \\
\hline Mimetic & & 0.74 & $\mathbf{0 . 8 5}$ & 0.66 \\
\hline $\begin{array}{l}\text { Our company adopted management controls because of } \\
\text { influence from other companies, in the manufacturing } \\
\text { sector. }\end{array}$ & 0.830 & & & \\
\hline $\begin{array}{l}\text { This company's management controls are similar to } \\
\text { that of other companies in the manufacturing sector. }\end{array}$ & 0.733 & & & \\
\hline $\begin{array}{l}\text { This company adheres strictly with norms in the } \\
\text { manufacturing sector. }\end{array}$ & 0.869 & & & \\
\hline
\end{tabular}

